\title{
Site C0011
}

\author{
Expedition 319 Scientists $^{2}$
}

\section{Chapter contents}

Background and objectives...........

Operations.................... 2

References.................. 2

Table .......................

${ }^{1}$ Expedition 319 Scientists, 2010. Site C0011. In Saffer, D., McNeill, L., Byrne, T., Araki, E., Toczko, S., Eguchi, N., Takahashi, K., and the Expedition 319 Scientists, Proc. IODP, 319: Tokyo (Integrated Ocean Drilling Program Management International, Inc.).

doi:10.2204/iodp.proc.319.105.2010

2Expedition 319 Scientists' addresses.

\section{Background and objectives}

Integrated Ocean Drilling Program (IODP) Site C0011 (proposed Site NT1-07) is a riserless drilling site located $\sim 30 \mathrm{~km}$ seaward (southeast) of the subduction trench and is the primary site for IODP Expedition 322 (Saito et al., 2009). Because of a combination of time constraints and the limited availability of coring technicians, the primary contingency sites for IODP Expedition 319 , including drilling and casing a hole at IODP Site C0002 and drilling and coring proposed Site NT1-01, were not possible. After discussion with the Nankai Trough Seismogenic Zone Experiment (NanTroSEIZE) Project Management Team and the Co-Chief Scientists of Expedition 322 to define a plan that would best advance overall NanTroSEIZE scientific objectives, we opted to move to Site C0011 and drill with the same suite of logging-while-drilling (LWD)/measurement-while-drilling (MWD) tools used at IODP Site C0010.

The anticipated geology at Site C0011 was similar to previously drilled Ocean Drilling Program Site 1177 (Moore, Taira, Klaus, et al., 2001). The uppermost $\sim 340 \mathrm{~m}$ was thought to comprise distal trench wedge turbidites overlying the hemipelagic mudstone of the upper Shikoku Basin facies. At $\sim 340$ meters below seafloor (mbsf), prominent reflectors were expected to coincide with the boundary between the upper and lower Shikoku Basin facies. From $~ 720$ to 860 mbsf within the lower Shikoku Basin, a series of high-amplitude seismic reflectors were interpreted as turbidite sands (Moore, Taira, Klaus, et al., 2001; Ike et al., 2008). The depth to basement was expected to be $\sim 1200$ mbsf.

The results from the LWD/MWD data at Site C0011 will be described in the Expedition 322 Proceedings volume; here we provide a brief overview of the objectives and operations conducted during the final 5 days of Expedition 319. Our objectives/goals at this site were to:

- Set transponders at the seafloor in advance of Expedition 322, in order to gain time $(\sim 24 \mathrm{~h})$ for their coring objectives;

- Drill with LWD/MWD; and

- Define sand body thicknesses and properties within the lower Shikoku Basin facies between 720 and 860 mbsf using gamma and resistivity logs, which was one key scientific goal of Expedition 322 (described in detail in Saito et al., 2009). 
LWD/MWD drilling included two phases: (1) drilling as fast as possible to 350 mbsf while recording data and (2) drilling at a controlled rate of penetration below 350 mbsf to a target depth of $\sim 900 \mathrm{mbsf}$ in order to obtain high-quality LWD resistivity image data in the lower Shikoku Basin facies.

\section{Operations Transit to Site C0011}

While recovering the transponders at Site C0010 following completion of operations, the drill pipe was set up and racked in preparation for running into the next hole. The D/V Chikyu then transited to Site C0011. The location was reached at $1700 \mathrm{~h}$ on 25 August 2009.

\section{Hole C0011A}

Schlumberger engineers and technicians prepared the Schlumberger LWD and MWD tools for assembly, prior to drilling Hole C0011A (target depth = as deep as possible or $900 \mathrm{mbsf}$, water depth $=4049 \mathrm{~m}$ ). Because the water depth was too great for remotely operated vehicle placement of transponders, the six transponders were dropped from the drillship; all were dropped by $0400 \mathrm{~h}$ on 26 August. At $0845 \mathrm{~h}$ on 26 August, the 121/4 inch bit LWD/MWD bottomhole assembly (BHA) (Table T1) was run into the hole, and a calibration check was conducted between the Big Head transducers on the ship and the transponders on the seafloor. At $1900 \mathrm{~h}$ on $26 \mathrm{Au}-$ gust, a prespud meeting was held to determine target depth (determined as $900 \mathrm{~m}$ LWD depth below seafloor [LSF]), jet-in program, and conditions for stopping drilling. Spud-in of Hole C0011A was achieved at $2239 \mathrm{~h}$ on 26 August, and the mudline (i.e., water depth) was confirmed to be $4049 \mathrm{~m}$ by MWD gamma ray measurement. After jetting in to $41 \mathrm{~m}$ drilling depth below seafloor, drilling the $12^{1 / 4}$ inch hole commenced. There were short wiper trips and sweeps to maintain good borehole condition and to prevent the BHA from getting stuck in the hole. After total depth (952 m LSF) was reached at $2359 \mathrm{~h}$ on 29 August, we spotted $121 \mathrm{~m}^{3}$ of $1.30 \mathrm{~g} / \mathrm{cm}^{3} \mathrm{kill}$ mud and began pulling out of the hole. The BHA reached the surface at $1300 \mathrm{~h}$ on 30 August, and the tools were laid down for LWD data recovery. Meanwhile, the Chikyu moved to the rendezvous point for the supply ship, the Kaiko, to load and backload cargo for Expedition 322.

\section{Transit to Yokkaichi}

After finishing laydown of the BHA and drill pipe and finishing cargo loading with the Kaiko, the supply ship was released and the Chikyu continued moving to Ise Bay to dock at the port of Yokkaichi, Japan, reaching the headlands at $1600 \mathrm{~h}$ on $30 \mathrm{Au}-$ gust.

\section{References}

Ike, T., Moore, G.F., Kuramoto, S., Park, J.-O., Kaneda, Y., and Taira, A., 2008. Variations in sediment thickness and type along the northern Philippine Sea plate at the Nankai Trough. Isl. Arc, 17(3):342-357. doi:10.1111/ j.1440-1738.2008.00624.x

Moore, G.F., Taira, A., Klaus, A., et al., 2001. Proc. ODP, Init. Repts., 190: College Station, TX (Ocean Drilling Program). doi:10.2973/odp.proc.ir.190.2001

Saito, S., Underwood, M.B., and Kubo, Y., 2009. NanTroSEIZE Stage 2: subduction inputs. IODP Sci. Prosp., 322. doi:10.2204/iodp.sp.322.2009

Publication: 31 August 2010

MS 319-105 
Table T1. Bottom-hole assembly, Hole C0011A. (See table note.)

\begin{tabular}{lcc}
\hline \multicolumn{1}{c}{ BHA component } & $\begin{array}{c}\text { Length } \\
(\mathrm{m})\end{array}$ & $\begin{array}{c}\text { Cumulative length } \\
(\mathrm{m})\end{array}$ \\
\hline 12-1/4 inch bit & 0.28 & 0.28 \\
RAB-8 (solid float/12-1/8 inch sleeve) & 3.78 & 4.06 \\
Telescope 825 HF & 8.50 & 12.56 \\
12-1/4 inch stabilizer & 2.34 & 14.90 \\
8 inch nonmagnetic drill collar & 9.13 & 24.03 \\
8-1/2 inch drilling collar & 9.30 & 33.33 \\
8-1/2 inch drilling collar & 9.30 & 42.63 \\
8-1/2 inch drilling collar & 9.30 & 51.93 \\
8-1/2 inch drilling collar & 9.30 & 61.23 \\
8-1/2 inch drilling collar & 9.30 & 70.53 \\
8-1/2 inch drilling collar & 9.30 & 79.83 \\
Mechanical jar & 10.70 & 90.53 \\
8-1/2 inch drilling collar & 9.30 & 99.83 \\
8-1/2 inch drilling collar & 9.30 & 109.13 \\
8-1/2 inch drilling collar & 9.30 & 118.43 \\
8-1/2 inch drilling collar & 9.30 & 127.73 \\
8-1/2 inch drilling collar & 9.30 & 137.03 \\
Crossover sub & 1.00 & 138.03 \\
5-7/8 inch 26.40 drill pipe (steel) & 10.00 & 148.03 \\
\hline
\end{tabular}

Note: $\mathrm{BHA}=$ bottom-hole assembly. 